\title{
Job Satisfaction of a Physical Education \\ Teacher as Seen by School Community
}

Authors' contribution:

A) conception and design of the study

B) acquisition of data

C) analysis and interpretation of data

D) manuscript preparation

E) obtaining funding

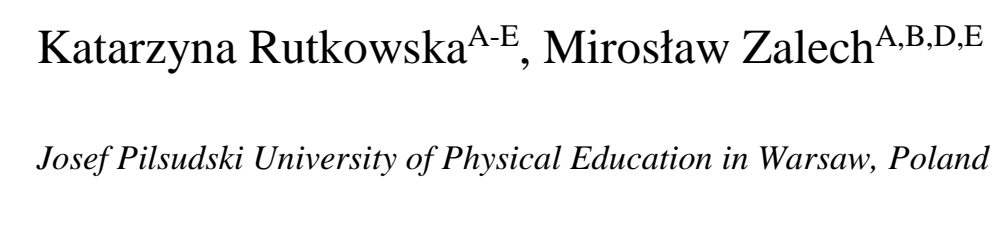

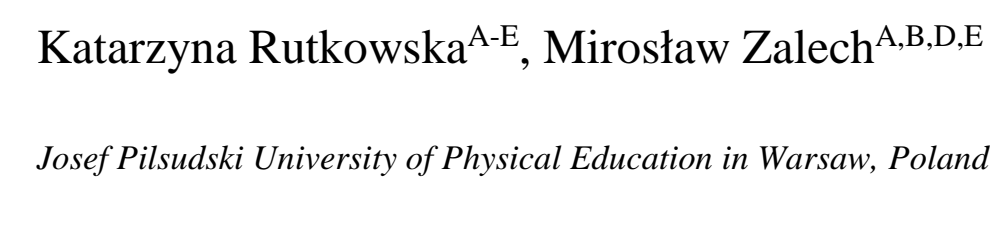 \\ .
}

\section{ABSTRACT}

\begin{abstract}
In A high level of satisfaction with a job influences the effectiveness and increases the quality of performed tasks. In the case of physical education teachers it is connected not only with a higher commitment to passing knowledge and skills but also with instilling passion in their students. The aim of the study was to analyse how school community perceives job satisfaction of physical education teachers. The research included 148 teachers and 171 students who were divided into three groups by means of random-purposive sampling. The groups were as follows: physical education teachers $(n=22)$, teachers of other subjects $(n=22)$ and students $(n=22)$. The results obtained from these respondents $(n=66)$ were subjected to further analysis. In the study a modified Polish version of the Satisfaction with Life Scale (SWLS) prepared by Juczyński (2001) was used. It made it possible to diagnose the job satisfaction of physical education teachers. The analyses revealed that the subjects assess the job satisfaction of a physical education teacher at an average or low level. This assessment showed significant differences between physical education teachers and teachers of other subjects. The study also revealed differences between groups with regard to two out of five scores in the SWLS.
\end{abstract}

KEYWORDS job satisfaction, relationships, teachers, physical education, students

\section{Introduction}

Previous studies on the image of teachers mainly focused on particular traits and competences (Lew, 1977; Zalech, 2011) and tried to evaluate them by creating certain models. However, they rarely referred to the issue of teachers' satisfaction with their job. Nevertheless, it seems that in such a specific professional group as physical education teachers, job satisfaction may influence the way a teacher is perceived by people, especially in the context of professional challenges. This, in turn, may affect the efficiency in fulfilling professional tasks. The research indicated that low job satisfaction may be a symptom of professional burnout (Koustelios, \& Tsigilis, 2005) or may affect the efficiency while working with students (Blase, 1986). It was also noted that there exists a correlation between job satisfaction and management style represented by physical education teachers (Rizi et al., 2013), as well as between job satisfaction and management style preferred by their superiors (Ehsani, 2010). Additionally, the research revealed that the level of teachers' job satisfaction is also correlated with working experience. Individuals with shorter working experience reveal a higher job satisfaction than novices and teachers with longer 
experience (Demirtas, 2010). It also turned out that self-esteem and positive relations with colleagues and superiors were variables which significantly influenced the feeling of community spirit at school. It is community spirit and emotional exhaustion that affect job satisfaction, while exhaustion and satisfaction influence a teacher's decision to leave the job (Skaalvik, \& Skaalvik, 2011b). Moreover, Hakanen, Bakker, \& Schaufeli (2006) noted that both emotional exhaustion and depersonalisation are correlated with selfassessment of one's own health and with the ability to work. It is a physical education teacher who should be a role model, however, not only in terms of appearance and behaviour but also attitude towards holistically perceived health. In this context a physical education teacher exerts significant (but smaller than the family) influence on the shaping of pro-health habits and encouraging youth to be physically active. Teachers set an example, inter alia, through manifesting and caring about their own fitness and health, through their professional skills, psychosocial skills but also through involvement and satisfaction with their job (Stelzer, 2005; Gold et al., 2012).

Since the 1990s a growing popularity of positive psychology dealing with issues concerning welfare and subjectively perceived well-being that form the quality of life has been observed. Various analyses revealing the sources of general life satisfaction among different social and professional groups have been performed and presented. External circumstances and conditions bringing happiness as well as individual predispositions for feeling satisfied have been analysed (Lykken, \& Tellegen, 1996; Lyubomirsky, \& Lepper, 1999). The previous research indicated that the major factors shaping the level of satisfaction with a job among teachers are their social surroundings and relations with various reference groups (Scheopner, 2010; Skaalvik, \& Skaalvik, 2011b). In this context, it is worth taking up research on job satisfaction as experienced by physical education teachers and as seen by school community, i.e., by other teachers and students for whom a physical education teacher should be a role model of physical fitness and healthy lifestyle. However, there are no studies in the literature which would indicate how these groups perceive teachers and their satisfaction with the participation in didactic process and with professional life.

The aim of the research was to analyse job satisfaction of physical education teachers as seen by themselves and to compare it with the level of their job satisfaction as seen by the school community (other teachers and students).

\section{Material and methods}

The research included 148 teachers and 171 students from five upper-secondary schools from different cities of Lubelskie voivodeship. From among the examined teachers a group of physical education teachers was selected. Such variables from this group as population, gender, age and working experience served as selection criteria for the remaining two control groups. The results of 66 people from the following groups were analysed:

- group I: 22 physical education teachers - 9 women and 13 men aged 26-55 (M=39.50, $\mathrm{SD}=8.21)$, who had minimum 3-year-long, maximum 30-year-long working experience ( $\mathrm{M}=14.86, \mathrm{SD}=8.11)$,

- group II: teachers of subjects other than physical education. The group was created by purposive sampling (pair sampling taking into account four variables: population, age, gender and working experience). From among 126 teachers, 22 respondents were selected, i.e., 9 women and 13 men aged 30-54 ( $M=40.09, S D=7.76)$, with working experience between 5 and 29 years $(M=14.95$, $\mathrm{SD}=8.14)$. No significant differences between group I and II concerning age $(\mathrm{U}=233.50 ; \mathrm{p}=0.84)$ and working experience $(\mathrm{U}=240.00 ; \mathrm{p}=0.96)$ were noted,

- group III: consisted of final-year students from upper-secondary schools. From among 171 students participating in the research, 22 respondents aged 18-19 were randomly selected ( $M=18.36$, $\mathrm{SD}=0.49$ ). Population and gender of the selected respondents were controlled (9 women, 13 men).

In the research a modified Polish version (prepared by Z. Juczyński) of the Satisfaction with Life Scale (SWLS by E. Diener, R.A. Emmons, R.J. Larson, S. Griffin) was used. The SWLS makes it possible to diagnose life satisfaction in the context of selected criteria (Juczyński, 2001). The implemented 
modifications (presented in Table 1) were inspired by adaptations applied in other studies (Rutkowska, 2010). The terms concerning life satisfaction were replaced with terms referring to job satisfaction of physical education teachers. It allowed for getting to know the opinion of school community. A modified version of the scale was called mod. SWLS. The significance of differences between the groups was assessed with Mann-Whitney U test.

Table 1 . The modified version of the scale used to measure job satisfaction of a physical education teacher

\section{Statements of mod. SWLS}

\section{Statement 1}

In many aspects a professional career of physical education teachers is almost ideal.

\section{Statement 2}

Work conditions of physical education teachers are excellent.

\section{Statement 3}

Physical education teachers are satisfied with their job.

\section{Statement 4}

Physical education teachers have achieved their most significant work objectives.

\section{Statement 5}

If physical education teachers could start their career again, they would not change almost anything.

Source: own study based on the SWLS modified by Z. Juczyński, Measurement tools in health promotion and psychology. Psychological Testing Laboratory PTP, Warsaw 2001.

\section{Results}

Due to the fact that it was a pilot study and there were no norms set, the authors introduced an additional system of calculations. The general result obtained by every respondent was divided by 5 (5 statements from the scale) and 7 (the respondents marked the statements with maximum 7 points). The results in the range of $\langle 0 ; 1\rangle$, for which a common denominator was found, were categorised according to sthène scale (1-4 - low scores, 5-6 - average scores, 7-10 - high scores) (Brzeziński, 1996). Table 2 presents the raw score for the five statements obtained from the whole group $(\mathrm{N}=66)$. It suggests that the respondents believe that job satisfaction of physical education teachers is on an average level.

Table 2. The general raw score (RS) and calculated score (CS) obtained during the study with the used modified SWLS

\begin{tabular}{c|c|c}
\hline \multirow{2}{*}{$\begin{array}{c}\text { General score } \\
\text { mod. SWLS }\end{array}$} & RS $(\mathbf{M} \pm$ SD) & CS (M \pm SD) \\
\cline { 2 - 3 } & $18.98 \pm 5.24$ & $0.54 \pm 0.15$ \\
\hline
\end{tabular}

Source: own study.

Next, the obtained results were divided into three groups: low, average and high scores. This made it possible to analyse their distribution (Figure 1). Every third person examined believed that a physical education teacher's job satisfaction is at a low level. Nearly $14 \%$ of the respondents stated that job satisfaction in this group is at a high level. 


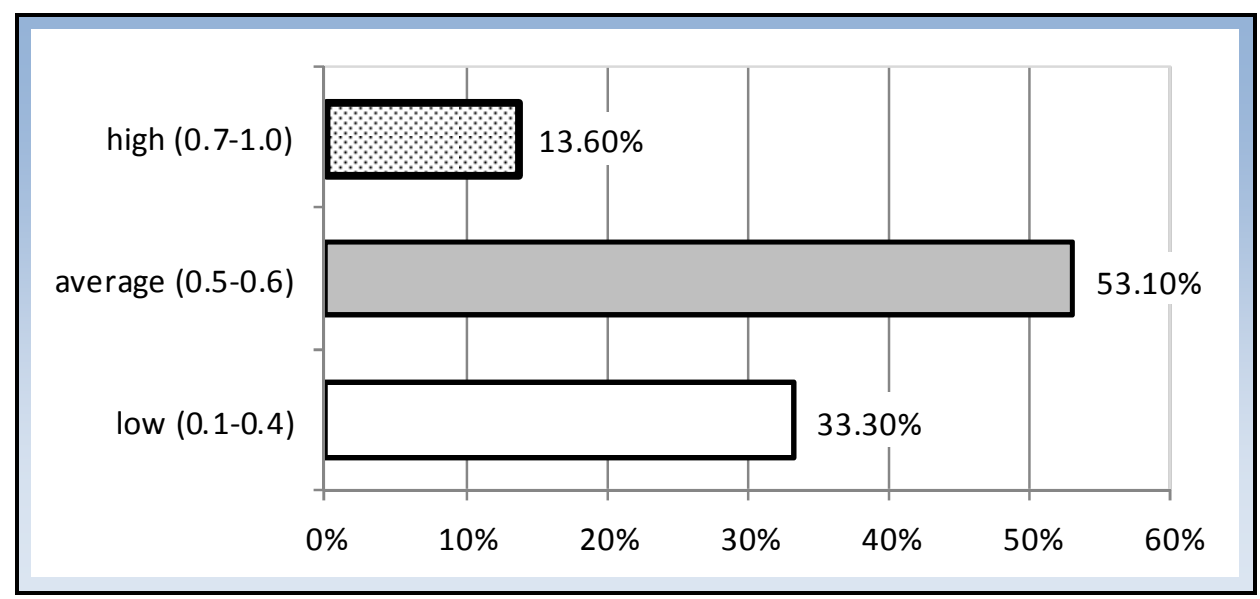

Figure 1. Categories of calculated scores - general score for modified SWLS (percentage distribution) Source: own study.

A similar analysis of raw scores (RS) and calculated scores (CS) was conducted for every statement in modified SWLS for all the respondents $(\mathrm{N}=66)$. Table 3 presents mean raw scores $(\mathrm{RS})$ and calculated scores (CS). The highest scores from among all the assessed statements were obtained in statement 3 (Physical education teachers are satisfied with their job), while the lowest scores were noted in statement 2 (Work conditions of physical education teachers are excellent).

Table 3. Raw scores (RS) and calculated scores (CS) obtained in particular statements during the study with modified SWLS

\begin{tabular}{c|c|c}
\hline Statement in mod. SWLS & WS $(\mathbf{M} \pm$ SD) & WP $(\mathbf{M} \pm$ SD) \\
\hline Statement 1 & $3.62 \pm 1.43$ & $0.52 \pm 0.20$ \\
Statement 2 & $3.32 \pm 1.51$ & $0.47 \pm 0.21$ \\
Statement 3 & $4.50 \pm 1.45$ & $0.64 \pm 0.21$ \\
Statement 4 & $3.89 \pm 1.25$ & $0.56 \pm 0.18$ \\
Statement 5 & $3.65 \pm 1.39$ & $0.54 \pm 0.20$ \\
\hline
\end{tabular}

Source: own study.

Mean scores in the case of four out of five statements assessed by the respondents $(\mathrm{N}=66)$ indicated an average level of job satisfaction. The four statements referred to the following aspects:

a) statement - a professional career of physical education teachers is almost ideal,

b) a physical education teacher's job satisfaction,

c) achieving the most significant professional objectives by a teacher,

d) tendencies for changes in professional career.

The statement assessed below the average referred to the conditions in which a physical education teacher works.

A detailed analysis of particular scores revealed that over $40 \%$ of the respondents gave low marks in statement 1 that referred to the assumption that a physical education teacher's professional career is almost ideal. One in five respondents assessed it on a high level. Nearly half of the respondents believed that physical education teachers are satisfied with their job (statement 3). Over $1 / 4$ of the examined group marked the realisation of professional objectives by physical education teachers (statement 4) with a low score. About 35\% of the respondents gave low marks in statement 5 ("If physical education teachers could start their career again, they would not change almost anything"). Nearly $60 \%$ of the respondents gave low marks in statement 2 that referred to the work conditions of physical education teachers (Figure 2).

The next stage (Tables $4 \& 5$ ) included the analysis of raw scores obtained by three groups ofrespondents, i.e., physical education teachers (group I), teachers of other subjects (group II) and students (group III).

Physical education teachers assessed their job satisfaction at a lower level than teachers of other subjects (Table 4). 


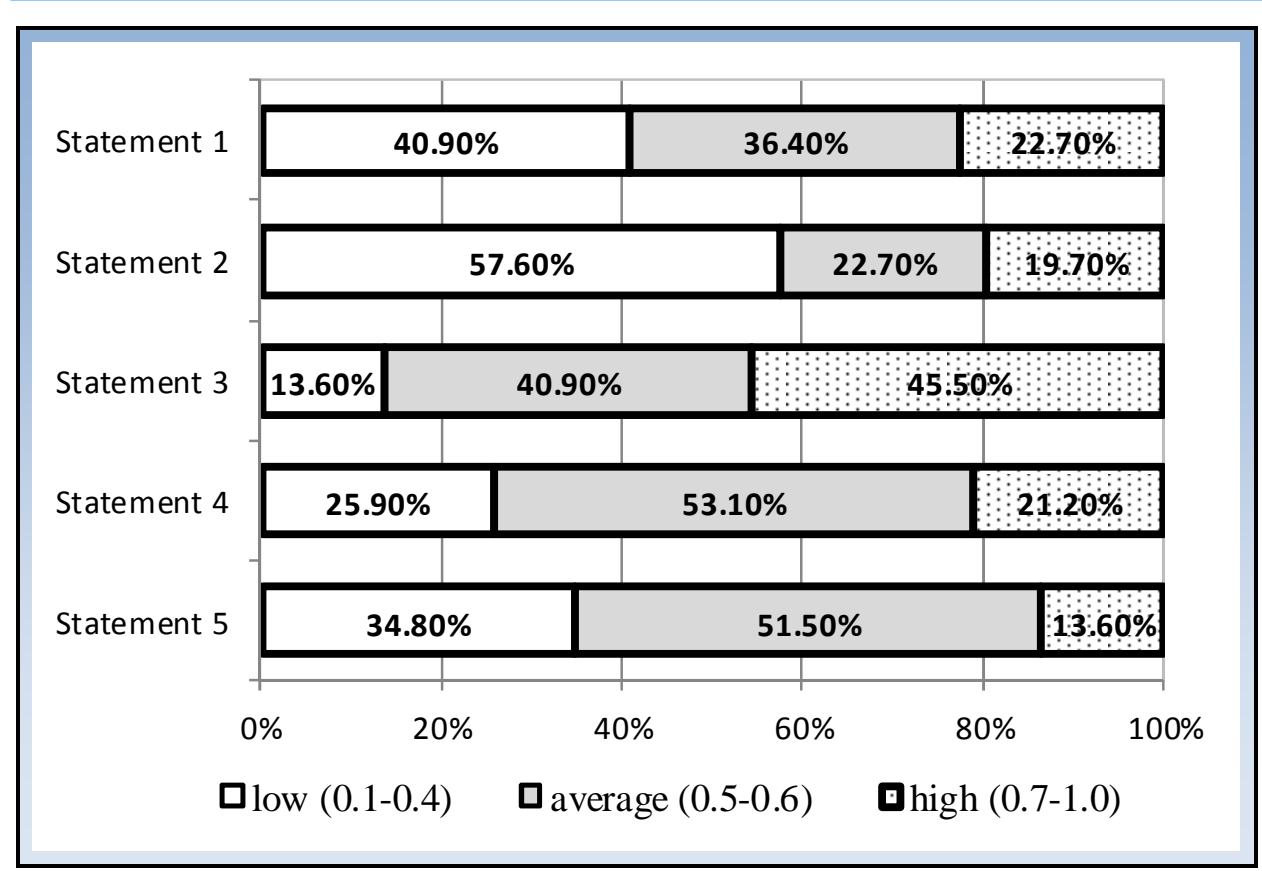

Figure 2. Categories of calculated scores - scores obtained for particular statements of modified SWLS (percentage distribution)

Source: own study.

Table 4. Intergroup comparisons (raw scores) - general scores for modified SWLS

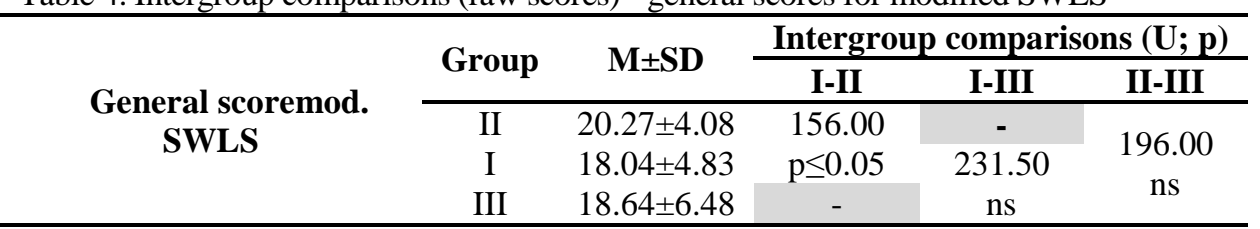

Source: own study.

Teachers of other subjects believed that the career of a physical education teacher is close to ideal; however, physical education teachers themselves and their students perceived it differently. In turn, physical education teachers noted a higher tendency for changes in the course of career of the representatives of their profession than their students and teachers of other subjects (Table 5).

Table 5. Intergroup comparisons (raw scores) - scores obtained for particular statements of modified SWLS

\begin{tabular}{|c|c|c|c|c|c|}
\hline \multirow{2}{*}{$\begin{array}{c}\text { General score mod. } \\
\text { SWLS }\end{array}$} & \multirow{2}{*}{ Group } & \multirow{2}{*}{$\mathbf{M} \pm \mathbf{S D}$} & \multicolumn{3}{|c|}{ Intergroup comparisons $(\mathrm{U} ; \mathbf{p})$} \\
\hline & & & I-II & I-III & II-III \\
\hline \multirow{3}{*}{ Statement 1} & II & $4.14 \pm 1.08$ & 155.50 & - & \multirow{3}{*}{$\begin{array}{l}160.50 \\
\mathrm{p} \leq 0.05\end{array}$} \\
\hline & I & $3.50 \pm 1.18$ & $\mathrm{p} \leq 0.05$ & 231.50 & \\
\hline & III & $3.23 \pm 1.82$ & - & ns & \\
\hline \multirow{3}{*}{ Statement 2} & II & $3.36 \pm 1.46$ & 223.00 & - & \multirow{3}{*}{$\begin{array}{c}237.00 \\
\text { ns }\end{array}$} \\
\hline & I & $3.18 \pm 1.43$ & ns & 220.00 & \\
\hline & III & $3.41 \pm 1.68$ & - & $\mathrm{ns}$ & \\
\hline \multirow{3}{*}{ Statement 3} & II & $4.59 \pm 1.18$ & 239.00 & - & \multirow{3}{*}{$\begin{array}{c}212.00 \\
\text { ns }\end{array}$} \\
\hline & I & $4.54 \pm 1.44$ & ns & 224.00 & \\
\hline & III & $4.36 \pm 1.73$ & - & ns & \\
\hline \multirow{3}{*}{ Statement 4} & II & $4.18 \pm 1.10$ & 186.00 & - & \multirow{3}{*}{$\begin{array}{c}198.00 \\
\text { ns }\end{array}$} \\
\hline & I & $3.77 \pm 1.31$ & ns & 231.50 & \\
\hline & III & $3.73 \pm 1.35$ & - & ns & \\
\hline \multirow{3}{*}{ Statement 5} & II & $4.00 \pm 1.41$ & 138.00 & - & \multirow{3}{*}{$\begin{array}{c}233.00 \\
\text { ns }\end{array}$} \\
\hline & I & $3.04 \pm 1.04$ & $\mathrm{p} \leq 0.01$ & 148.50 & \\
\hline & III & $3.91 \pm 1.51$ & - & $\mathrm{p} \leq 0.05$ & \\
\hline
\end{tabular}

ns - non-significant differences

Source: own study. 


\section{Discussion}

On the basis of the obtained results it may be stated that work conditions of physical education teachers were marked with the lowest scores. It may be caused by the fact that all the examined groups noted various obstacles that this professional group encounters. In the literature of the subject teachers usually indicate problems with relations and/or problems resulting from the lack of institutional and social support (Pyżalski, 2008). These factors to a large extent influence the fact that working conditions are marked with such low scores by all the examined groups. The numerous problems that contemporary teachers encounter include these referring to meeting the requirements of being accepted/liked and to increasing the prestige of the job or teachers' status in the society. Undoubtedly job satisfaction affects the image created by teachers themselves and the image seen by the community. Therefore, apart from the need for reviewing education systems, work organisation and programme verification, also the need for improving particular competences by teachers is stressed so that they can deal with difficult situations better and fulfil their professional role more effectively. It has been suggested that (especially at the beginning of the professional career of a physical education teacher) it is worth introducing the role of mentor in the system (Morgan,\& Hansen, 2008; Jenkinson, \& Benson, 2010; Shoval, Erlich, \& Fejgin, 2010; Coutarel, \& Fiard, 2012). This is a significant suggestion which is also supported by the results of this research. Over a third of the respondents assessed the course of professional career of physical education teachers on a low level, while half of the respondents - on an average level. It may be worth implementing the role of a guide, leader or coach supporting physical education teachers also in terms of planning and managing their professional objectives. Therefore, it seems that job satisfaction of physical education teachers and the way it is perceived by the school community inspire and influence work effectiveness. Additionally, it contributes to fuller integrity with professional community, which, in turn, is related to the chance to get higher social support needed by school community.

One of the significant tasks which physical education teachers fulfil simultaneously obtaining appropriate cognitive, behavioural, affective or social results among their students in a conscious and controlled way, is to create an atmosphere of motivation (awakening internal motivation and satisfaction and building a positive attitude towards physical activity) (Ntoumanis, \& Biddle, 1999; Papaioannou et al., 2007). Naturally, it is easier to awaken and sustain this engagement for teachers who are aware of their own high efficiency (Martin et al., 2008), and they are also perceived in this way by the community. They will be seen by school community as people satisfied with their professional role. Job satisfaction experienced by them and seen by others is one of the elements of building a positive organisational climate and of a better contact with students.

The research revealed that physical education teachers recognised a higher need for changes in their professional career than the school community. It indicates that they noted their previous mistakes which they would have been able to avoid or limit their results with the current state of knowledge. The experience gained should not be wasted and, thus, it is worth making teachers aware of the fact that their professional development is not closed and it should include various spheres of their activity. At present teachers' activity is mainly focused on the areas defined by school curricula. They do not see opportunities for development in other areas. One of such opportunities is the issue of shaping one's own positive image in the work community. It should not be limited only to gaining practical skills concerning public relations. Fuller and more measurable effects are brought about by investing in various psychosocial skills and competences, as well as reinforcing and highlighting strengths of the teachers. Taking into account the results of the research, it may be concluded that it will increase stated life satisfaction which also includes job satisfaction (Ignat, 2010). To sum up, it should be concluded that the improvement of work conditions and building an atmosphere of support also in the field of professional development are significant solutions which are indicated in the literature of the subject as those reinforcing job satisfaction and engagement in work (Papinczak, 2012). 
The discussion on personal and professional satisfaction is particularly important the context of a problem of professional burnout, which affects a large group of teachers. The loss of idealism, engagement and job satisfaction typical of this syndrome affect not only the quality of work but also relations (including image). Therefore, the level of job satisfaction may be one of the indicators of professional burnout. Moreover, it was proved that it may also be one of predictors of potential resignation from work (Wolpin, Burke, \& Greenglass, 1991; Skaalvik, \& Skaalvik, 2011a). In the situation when teachers (also physical education teachers) are exposed to the risk of professional burnout, it is worth doing research that takes into account a deeper analysis of how job satisfaction is perceived and how it may be improved.

\section{Conclusions}

The research was aimed at recognising the level of job satisfaction felt by physical education teachers and how it is perceived by the representatives of school community (teachers of other subjects and students). The obtained results made it possible to draw a picture of physical education teachers' job satisfaction as seen by the community and compare it with their self-assessment. It was proved that physical education teachers marked such aspects as:

1. General level of job satisfaction;

2. Professional choices, and;

3. Professional career close to ideal with lower scores than their colleagues teaching other subjects.

Physical education teachers believed that their career was far from ideal. However, school community, students and teachers of other subjects had varied opinions. Students as well as physical education teachers noted drawbacks which may affect gaining full satisfaction with their professional career. Nevertheless, teachers of other subjects believed that the career of physical education teachers is to a large extent close to ideal. These discrepancies between groups of teachers may bring about misunderstanding and conflicts or may lead to a situation in which a physical education teacher's image is different from reality. It may be affected by the wrong understanding of the job specificity and perceiving it as less important, less responsible or easier. In this case it seems that reliable information about physical education teachers' activity as well as sharing problems and trying to solve them together may be a significant factor bringing those opinions closer.

Both teachers of other subjects and students presented opinions statistically different from those expressed by physical education teachers as far as implementing changes in their professional career was concerned. If it were possible to start professional career again, physical education teachers would implement more changes in it than school community. It proves that physical education teachers are aware of their wrong decisions regarding their professional career. They could have been avoided with the help of a mentor or a guide, especially during the first years of a career, which might increase the level of job satisfaction.

Due to the fact that it was a pilot study and due to the complexity of perceiving and feeling job satisfaction by physical education teachers, the issue has not been analysed fully and the research needs to be continued. It is worth taking into account social and psychological competences in the research. It will make it possible to create a fuller image of physical education teachers' job satisfaction, which, in turn, will improve their image and perception in the community. The applied modification of the SWLS (Juczyński, 2001) became the basis for drawing attention to a significant course of research concerning physical education teachers' job satisfaction as a component which may not only increase self-esteem and effectiveness but also contribute to creating a desired image and prestige of the job among students and colleagues. 


\section{Acknowledgements}

The research accomplished within the framework of research project of Faculty of Physical Education and Sport in Biała Podlaska The Josef Pilsudski University of Physical Education in Warsaw - DS.171 financed by Ministry of Science and Higher Education.

\section{REFERENCES}

Blase, J. (1986). A qualitative analysis of sources of teacher stress: Consequences for performance, American Educational Research Journal, 23, 13-40.

Brzeziński, J. (1996). Metodologia badań psychologicznych /The methodology of psychological research/. Warsaw: PWN.

Coutarel, F., \& Fiard, J. (2012). Physical education and sport teachers' health: from expressed ill-being to hindrances of action, Work, 41, 5228-5230.

Demirtas, Z. (2010). Teachers' job satisfaction levels, Procedia-Social and Behavioral Sciences, 9, 1069-1073.

Ehsani, M. (2010). The Relationship of Management Style and Job Satisfaction among PE Teachers, Physical Culture and Sport. Studies and Research, 48(1), 71-83.DOI: 10.2478/v10141-010-0008-y

Gold, R.R., Petrella, J., Angel, J., Ennis, L.S., \& Woolley, T.W. (2012). The qualities of physical education teachers based upon students' perception of physical appearance, Journal of Instructional Psychology, 39(2), 92-104.

Hakanen, J.J., Bakker, A.B., \& Schaufeli, W.B. (2006). Burnout and work engagement among teachers, Journal of School Psychology, 43, 495-513.

Ignat, A.A. (2010). Teachers' satisfaction with life, emotional intelligence and stress reaction, Petroleum Gas University of Ploiesti Bulletin Educational Sciences Series, 57(2), 32-41.

Jenkinson, K.A., \& Benson, A.C. (2010). Barriers to providing physical education and physical activity in Victorian State Secondary Schools, Australian Journal of Teacher Education, 35(8,1), 1-17.

Juczyński Z. (2001). Narzędzia pomiaru w promocji i psychologii zdrowia /Measurement and promotion tools in health psychology/. Warsaw: Pracownia Testów Psychologicznych.

Koustelios, A., \& Tsigilis, N. (2005). The relationship between burnout and job satisfaction among physical education teachers: a multivariate approach. European Physical Education Review, 11(2), 189-203.

Lew, W.J. (1977). Teaching and the Teacher's Personality. Educational Journal, 6, 9-20.

Lykken D., \& Tellegen A. (1996). Happiness is a stochastic phenomenon. Psychological Science, 7, 186-189.

Lyubomirsky, S., \& Lepper, H.S. (1999). A measure of subjective happiness: preliminary reliability and construct validation. Social Indicators Research, 46, 137-155.

Martin, J.J., McCaughtry, N., Hodges-Kulinna, P., \& Cothean, D. (2008). The influences of professional development on teachers' self-efficacy toward educational change. Physical Education and Sport Pedagogy, 13(2), 171-190.

Morgan, P.J., \& Hansen, V. (2008). Classroom teachers' perception of the impact of barriers to teaching physical education on the quality of physical education programs. Research Quarterly for Exercise and Sport, 79(4), 506-516.

Nicaise, V., Cogérino, G., Bois, J.N., \& Amorose, A.J. (2006). Students' perception of teacher feedback and physical competence in physical education classes: gender effects. Journal of Teaching in Physical Education, 25, 36-57.

Ntoumanis, N., \& Biddle, S.J.H. (1999). A review of motivational climate in physical activity. Journal of Sports Sciences, 17, 643- 665.

Papaioannou, A.G., Tsigilis, N., Kosmidou, E., \&Milosis, D. (2007). Measuring perceived motivational climate in physical education. Journal of Teaching in Physical Education, 26, 236-259.

Papinczak, T. (2012). Perception of job satisfaction relating to affective organization commitment. Medical Education, 46(10), 953-962.

Rizi, R.M., Azadi, A., Farsani, M.E., \& Aroufzad, S. (2013). Relationship between leadership styles and job satisfaction among physical education organizations employees. European Journal of Sports and Exercise Science, 2(1), 7-11.

Rutkowska, K. (2010). Sytuacyjne poczucie kontroli a satysfakcja z podejmowanej przez studentów-sportowców działalności /Situational locus of control and satisfaction with activity undertaken by students-athletes/. In J. Tatarczuk 
(Ed.), Dobrostan, środowisko i sukces sportowy /Well-being, community and sports success/ (pp. 209-217). Lublin: Wydawnictwo NeuroCentrum.

Scheopner, A. (2010). Irreconcilable differences: teacher attrition in public and catholic schools. Educational Research Review, 5, 261-277.

Shoval, E., Erlich, I., \& Fejgin, N. (2010). Mapping and interpretating novice physical education teachers selfperceptions of strengths and difficulties. Physical Education and Sport Pedagogy, 15(1), 85-101.

Skaalvik, E.M., \& Skaalvik, S. (2011a). Teachers' feeling of belonging, exhaustion and job satisfaction: the role of school goal structure and value consonance. Anxiety, Stress and Coping, 24(4), 369-385.

Skaalvik, E.M., \& Skaalvik, S. (2011b). Teacher job satisfaction and motivation to leave the teaching profession: Relations with school context, feeling of belonging, and emotional exhaustion. Teaching and Teacher Education, 27(6), 1029-1038.

Stelzer, J. (2005). Promoting healthy lifestyles: Prescriptions for physical educators. Journal of Physical Education, Recreation \& Dance, 76(4), 26-29.

Wolpin, J., Burke, R.J., \& Greenglass, E.R. (1991). Is job satisfaction an antecedent or a consequence of psychological burnout? Human Relations, 44(2), 193-209.

Zalech, M. (2011). Elimination of Negative Character Features As an Element of Building a Positive Image of Physical Education Teacher. Polish Journal of Sport and Tourism, 18(3), 206-213.

AUTHOR'S ADDRESS: $\quad$ Katarzyna Rutkowska

Josef Pilsudski University of Physical Education in Warsaw

Faculty of Physical Education and Sport in Biala Podlaska

Akademicka 2

21-500 Biała Podlaska, Poland

Email: kr@psychologsportu.pl

Received: 15 April 2015; Accepted: 28 May 2015 